\title{
CLIMATE LITERACY AWARENESS AMONG PRESERVICE TEACHERS IN MALAYSIA
}

\author{
Nasir Nayan*, Hanifah Mahat, Mohmadisa Hashim, Yazid Saleh, \\ Saiyidatina Balkhis Norkhaidi \\ Universitas Pendidikan Sultan Idris, Malaysia \\ *e-mail: nasir@fsk.upsi.edu.my
}

\begin{abstract}
Among the efforts made to raise awareness concerning mitigation and adaptation to climate change is climate literacy acquired from the educational medium. Therefore, this article seeks to identify the level of awareness on climate literacy among preservice teachers in Malaysia. This study involved 500 final-year students from nine faculties at Sultan Idris Education University using the stratified sampling method. A questionnaire instrument was used to get feedback, containing four study variables, namely the knowledge, attitudes, skills, and practices of climate change mitigation and adaptation. The findings showed that the knowledge of and attitudes towards climate change mitigation and adaptation variables were at high levels, while the skills and practices of climate change mitigation and adaptation variables were at moderate levels. Thus, this indicates that students' knowledge of and attitudes towards climate change mitigation and adaptation were good and satisfactory, but not the skills and practices of climate change mitigation and adaptation, which were still moderate and could be improved over time. The findings and issues that have been studied can be used as a reference and guide for universities, educators and ministries in improving students' climate literacy, aiming for a more sustainable life.
\end{abstract}

Keywords: knowledge, attitudes, skills, practices, mitigation, adaptation.

\section{KESADARAN LITERASI IKLIM DI ANTARA GURU PELESTARIAN DI MALAYSIA}

\begin{abstract}
Abstrak: Di antara upaya yang dilakukan untuk meningkatkan kesadaran sehubungan dengan mitigasi dan adaptasi terhadap perubahan iklim adalah literasi iklim yang diperoleh dari media pendidikan. Oleh karena itu, artikel ini berupaya mengidentifikasi tingkat kesadaran akan literasi iklim di antara para guru pra-jabatan di Malaysia. Penelitian ini melibatkan 500 mahasiswa tahun terakhir dari sembilan fakultas di Universitas Pendidikan Sultan Idris menggunakan metode stratified sampling. Instrumen kuesioner digunakan untuk mendapatkan umpan balik, yang berisi empat variabel studi, yaitu pengetahuan, sikap, keterampilan, dan praktik mitigasi dan adaptasi perubahan iklim. Temuan menunjukkan bahwa pengetahuan dan sikap terhadap mitigasi perubahan iklim dan variabel adaptasi berada pada tingkat tinggi, sedangkan keterampilan dan praktik mitigasi perubahan iklim dan variabel adaptasi berada pada tingkat sedang. Dengan demikian, ini menunjukkan bahwa pengetahuan dan sikap siswa terhadap mitigasi dan adaptasi perubahan iklim baik dan memuaskan, tetapi bukan keterampilan dan praktik mitigasi dan adaptasi perubahan iklim, yang masih moderat dan dapat ditingkatkan dari waktu ke waktu. Temuan dan masalah yang telah dipelajari dapat digunakan sebagai referensi dan panduan untuk universitas, pendidik, dan kementerian dalam meningkatkan literasi iklim siswa, yang bertujuan untuk kehidupan yang lebih berkelanjutan.
\end{abstract}

\section{Kata Kunci: pengetahuan, sikap, keterampilan, praktik, mitigasi, adaptasi}

\section{INTRODUCTION}

Climate change mitigation and adaptation have become today's major agenda for a balanced world ecosystem. These issues of climate change are of great importance as this phenomenon has resulted in natural disasters and drastic changes in the world's climate (United Nations, 2009).
Besides, this phenomenon also causes changes in human, plant and animal life ecosystems (World Health Organization, 2016). The major contributors to climate change are the result of human activities through the emission of gases from carbon elements, whether from vehicles, electric energy consumption or industries, 
which cause the earth to heat up and increase the average temperature of the earth, known as the global warming phenomenon (Ahmad \& Nour, 2015). Electricity generation is also the single largest source of carbon dioxide emissions $\left(\mathrm{CO}^{2}\right)$ from the combustion of fossil fuels such as coal, oil and natural gas (Hammond, 2007). However, uncontrollable global climate change has also resulted in natural disasters such as unpredictable typhoons and heavy rains that contribute to the occurrence of major floods. Besides affecting the environment, this phenomenon has also affected human health and caused discomfort. Various diseases such as damage to the eye lens, skin cancer, and even mutations in the human chromosomal system have occurred due to the implications of this event (World Health Organization, 2016). This can be seen more clearly when humans have Down Syndrome and Turner Syndrome as a result of chromosomal mutations (Gioconda, Denisse, \& Alfredo, 2016).

Climate change indirectly involves nature with its particular components, namely the atmosphere, hydrosphere, and biosphere. However, these changes are closely interrelated with humans turning climate change into a bigger issue. The impact of climate change will also return to the humans on this planet (Ledley, Gold, Niepold, \& McCaffrey, 2014). Communities should have knowledge concerning climate change and the actions to be followed to show that climate literacy has been understood. This is because climate change is contributed to by human actions. Communities should also have the knowledge and skills to influence their actions and decisions (Dupigny-Giroux, 2010). Every individual in a society has their roles, but to ensure effective solutions, appropriate approaches have to be taken to mitigate the effects of extreme climate change.

The applications of climate literacy are also different based on age groups so that the real meaning of climate literacy can be disseminated among the community (Kahan, Peter, Wittlin, Slovic, Ouelette, Braman, \& Mandel, 2012). Therefore, research on climate change is needed to address this issue. However, currently, most research regarding the climate has been more related to pure science to see the events of climate change and the impact on the environment and it still of studies that are related to human beings.
Studies on climate change and social science, especially the human knowledge of climate change, should be intensified to show the impact on human life, especially among university students. For that reason, this article aims to study from the perspective of social science in examining human awareness regarding climate change that gives impact to their lives involving student life. This is because university students are an educated group of people with the highest level of education, as well as the fact that they reflect today's knowledgeable young people who will lead the country in the future.

Literacy is traditionally defined as the ability to apply language for writing, reading, listening and communicating. In the current context, literacy refers to the ability to read and write at an appropriate level for communicating, or at a certain level that allows one to comprehend and communicate in a literate society (Mohamad \& Zurida, 2010). The United Nations Educational, Scientific and Cultural Organisation (UNESCO) expresses the definition of literacy as the ability to identify, understand, predict, create, communicate, count and use printed materials and written materials regarding in diversity context. Literacy involves a learning continuum that enables an individual to achieve his or her goals, build knowledge and potential and participate in society. Scientific literacy generally refers to the knowledge, skills, and attitudes that need to be implemented through problem-solving and decision-making approaches (Dupigny-Giroux, 2010). Climate literacy requires an understanding of three basic concepts, namely, that the earth's climate system can be understood and predicted, the area of climate studies is increasing, the cumulative understanding of the earth's climate system is still developing, and the studies with regard to climate rely on empirical evidence that can be published and certified through experimental studies (Niepold, Herring, \& McConville, 2007).

Therefore, climate-literate individuals understand the essential principles of the earth's climate system, know how to seek out true scientific information about the climate, discuss climate issues and climate change meaningfully and can make responsible and prudent decisions on actions that may affect the climate (Termizi \& Zuraida, 2010). Climate-science-literate individuals know that climate science can 
provide information about the decisions that can improve their quality of life. They have a fundamental knowledge of the climate system, whether it occurs naturally or as a result of human actions. Climate-literate individuals also understand that scientific knowledge of the climate can be obtained from observations, records, and computer models. They are also aware of the basic relationship between climate and human life and how the climate affects human health. They can assess the validity of a climate argument and use the information to support the decisions made.

However, studies on climate literacy have shown that the level of individual understanding is still weak in the context of behavior compared to knowledge. A study by Termizi \& Zurida (2010) showed that teachers' understanding of climate change issues was still at a moderate level and required attention, given that teachers were examples for students in school. Additionally, in the UNDP Asia-Pacific Human Development Report 2011, the effects of climate change had also impacted some of the social status functions such as sex, poverty, power, and access to resources (United Nations Development Programme, 2011). A study by Christensen \& Knezek (2015) shows that individual attitudes towards climate change can be changed when they are constantly monitored and given attention to climate change issues by practicing a sustainable and pro-environmental life. In the context of this study, climate literacy awareness involves the knowledge, understanding, application, analysis, synthesis, and assessment of the climate adaptation and mitigation system implemented through a learning process in the lecture halls, as stated in the Theory of Literacy Development (Holdaway, 1979). Suziana (2013) stated that the positive attitudes possessed can shape students' identity through the changes in the practice of climate change adaptation and mitigation. The KAP (Knowledge, Attitudes, and Practices) model developed by Schwartz (1976) also states that a person's practice is influenced by one's knowledge and attitudes as well. For that reason, in this study, climate literacy awareness is measured through four components, namely knowledge, attitudes, skills, and practices (Figure 1).

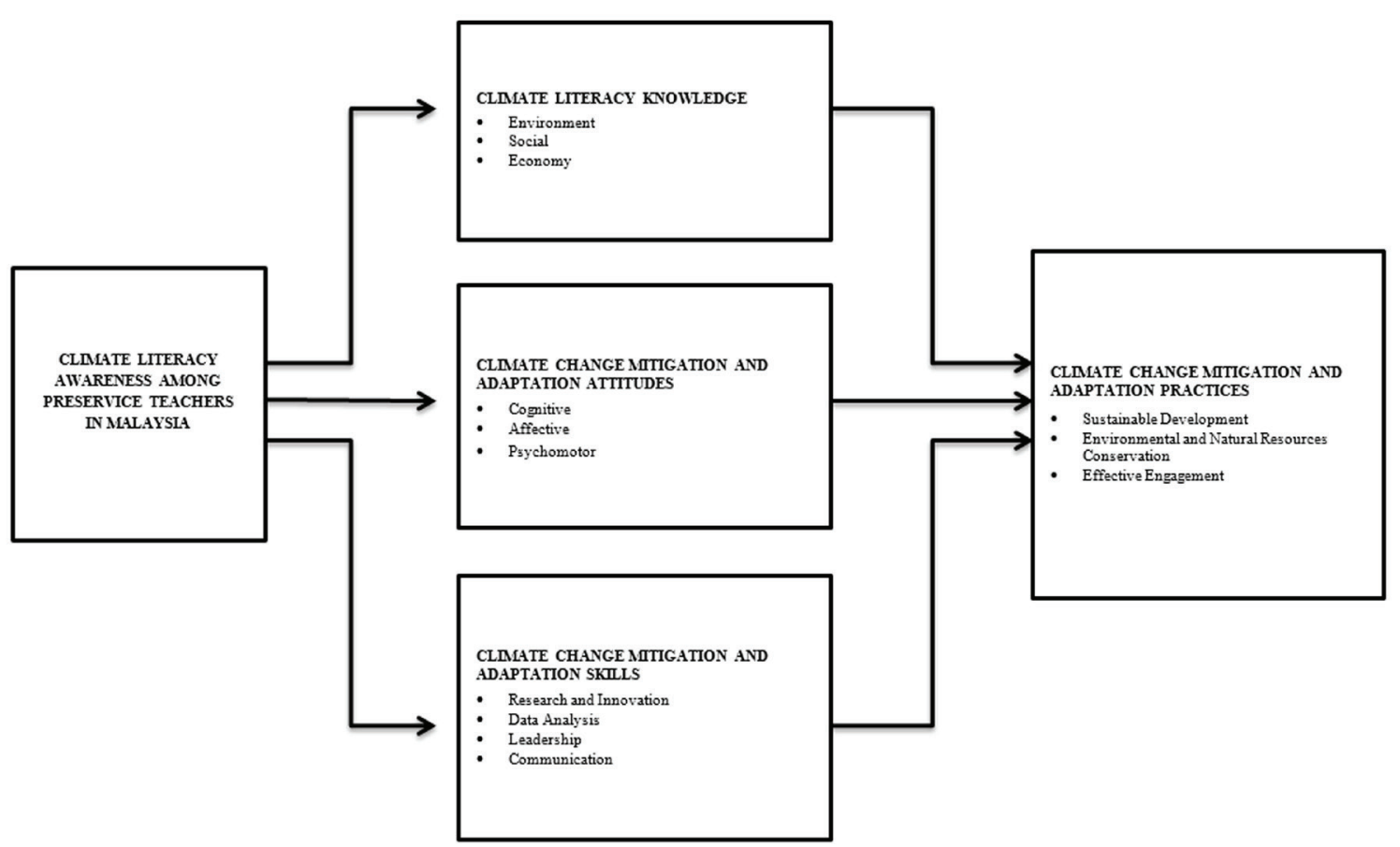

Figure 1. Components of Climate Literacy of Students 
The knowledge component was measured through three major elements of sustainability: environment, economy and social (Hanifah, Shaharudin, Mohmadisa, Nasir, \& Yazid, 2015). While attitudes in this study were measured in the aspect of cognitive, affective and psychomotor (Krathwohl, 2002; Szczytkoa, Stevensona, Petersonb, Nietfeldc, \& Strnad, 2018; Bloom, 1956). Next, the skills of climate change mitigation and adaptation were measured through research and innovation, data analysis, leadership, and communication. The formation of these practices, skills, and attitudes will influence the future career aspirations of the students. While the practices of climate change mitigation and adaptation component were measured from sustainable development, environmental and natural resources conservation, and effective engagement as stated in the National Policy on Climate Change Malaysia (Ministry of Natural Resources and Environment Malaysia, 2010). Therefore, the findings of this study are hoped to be a reference and guide for universities, educators and ministries in identifying the components that need to be improved to enhance students' climate literacy towards a more sustainable life.

The climate change awareness is essential to everybody nowadays. Awareness at the level of preservice teachers is important in Malaysia as constructed in the Malaysia National Philosophy of Education. It encompasses a concept of human existence that has a special characteristic known as the truth or self-awareness that enables the person to think, be intelligent and aware of moral values (Von Bertalanffy, 1968; Hasan, 2007). Transfer of Learning elements is one of the important features in education. The situation is similar to the educating climate change which is affecting around the globe nowadays. Educating the teachers with the learning transfer which is essential to spread and practiced knowledge (Kamarudin, 2010). Similar to the preservice teachers who will get posting to school and becoming a full-time teacher in the near future. If they too have no awareness of climate change, then how can such a transfer of learning happen? Melillo, Richmond, \& Yohe (2014) also stated that some cumulative impact will occur progressively and the need for action to educate people in order to reduce the damage. So one of the strengths in building action is the preservice teacher who becoming the teacher and educate the students on climate change.

\section{METHOD}

The methodology of this study was quantitative, using a questionnaire instrument to measure the four main variables of the study, namely knowledge, skills, attitudes, and practices. The climate elements emphasized in these variables were temperature, rain, wind, relative humidity, clouds, and air pressure. The study involved the final semester of education bachelor's degree students at Sultan Idris Education University (UPSI) in Tanjong Malim, Perak, Malaysia. The selection of this study location was because this university is an institution that provides preservice teachers for schools in Malaysia. Besides, UPSI is also one of the public universities in Malaysia. The UPSI location, situated in Tanjung Malim Perak Darul Ridzuan, has two campuses, namely Sultan Abdul Jalil Shah Campus (KSAJS) and Sultan Azlan Shah Campus (KSAS).

\section{Population and Samples}

This study was conducted at Sultan Idris Education University, Malaysia, involving 500 final-semester students from nine faculties at Sultan Idris Education University using stratified sampling. Table 1 descriptively shows the frequency and percentages of respondents' backgrounds based on faculty and the course of the 500 students involved in this study.

Table 1. Respondents' Background by Faculty

\begin{tabular}{lccc}
\hline Faculty & $\begin{array}{c}\text { Number of } \\
\text { Population }\end{array}$ & $\begin{array}{c}\text { Percentage } \\
\text { (\%) }\end{array}$ & $\begin{array}{c}\text { Number of } \\
\text { Samples }\end{array}$ \\
\hline Faculty of Language and Communication (FBK) & 1860 & 15.9 & 80 \\
Faculty of Music and Performing Arts (FMSP) & 475 & 4.1 & 20 \\
Faculty of Management and Economics (FPEK) & 1491 & 12.8 & 64 \\
Faculty of Education and Human Development (FPPM) & 1245 & 10.7 & 53 \\
Faculty of Human Sciences (FSK) & 1684 & 14.4 & 72 \\
\hline
\end{tabular}




\begin{tabular}{lccc}
\hline Faculty & $\begin{array}{c}\text { Number of } \\
\text { Population }\end{array}$ & $\begin{array}{c}\text { Percentage } \\
(\mathbf{\%})\end{array}$ & $\begin{array}{c}\text { Number of } \\
\text { Samples }\end{array}$ \\
\hline Faculty of Art, Computing and Creative Industry (FSKIK) & 1757 & 15.0 & 75 \\
Faculty of Science and Mathematics (FSMT) & 1074 & 9.2 & 46 \\
Faculty of Sports and Coaching (FSSKJ) & 1303 & 11.1 & 56 \\
Faculty of Technical and Vocational Education (FTV) & 801 & 6.9 & 34 \\
\hline Total & 11690 & 100 & 500 \\
\hline
\end{tabular}

\section{Study Instrument}

This study used a questionnaire as the research instrument, which consisted of five parts, namely parts $\mathrm{A}, \mathrm{B}, \mathrm{C}, \mathrm{D}$, and $\mathrm{E}$ (Table 2). Part A contained respondents' demographic information, while Parts B to E covered the study variables, namely climate change knowledge, climate change mitigation and adaptation attitudes, climate change mitigation, and adaptation skills, and climate change mitigation and adaptation practices.

Table 2. Respondent Questionnaire Information

\begin{tabular}{|c|c|c|c|c|}
\hline Part & Details & Constructs & $\begin{array}{l}\text { Number of } \\
\text { Items }\end{array}$ & Source of Items \\
\hline \multirow[t]{4}{*}{$\mathrm{A}$} & \multirow{4}{*}{$\begin{array}{l}\text { Background of } \\
\text { respondent }\end{array}$} & Age & 1 & \multirow{4}{*}{$\begin{array}{l}\text { Self-built according to the needs of the } \\
\text { study }\end{array}$} \\
\hline & & Semester & 1 & \\
\hline & & Gender & 2 & \\
\hline & & Races & 7 & \\
\hline \multirow[t]{3}{*}{ B } & \multirow{3}{*}{$\begin{array}{l}\text { Climate literacy } \\
\text { knowledge }\end{array}$} & Environment & 18 & \multirow{3}{*}{$\begin{array}{l}\text { Retrieved and modified from Stacy } \\
\text { (2016), The Office of the United } \\
\text { Nations High Commissioner for Human } \\
\text { Rights (OHCHR) (2015), The United } \\
\text { States Global Change Research Program } \\
\text { (Melillo et al., 2014), UK Environment } \\
\text { Change Network. (2016), Global and } \\
\text { Region Climate Change (2014), Kristen } \\
\text { (2016), Subramaniam (2014) and } \\
\text { Hanifah et al. (2015) }\end{array}$} \\
\hline & & Social & 28 & \\
\hline & & Economy & 38 & \\
\hline \multirow[t]{3}{*}{$\mathrm{C}$} & \multirow{3}{*}{$\begin{array}{l}\text { Climate change } \\
\text { mitigation and } \\
\text { adaptation } \\
\text { attitudes }\end{array}$} & Cognitive & 8 & \multirow{3}{*}{$\begin{array}{l}\text { Retrieved and modified from Global and } \\
\text { Region Climate Change (2014), and } \\
\text { Franzen, Bennett, \& Wilder (2017) }\end{array}$} \\
\hline & & Affective & 15 & \\
\hline & & Psychomotor & 20 & \\
\hline \multirow[t]{4}{*}{$\mathrm{D}$} & \multirow{4}{*}{$\begin{array}{l}\text { Climate change } \\
\text { mitigation and } \\
\text { adaptation skills }\end{array}$} & Research and innovation & 7 & \multirow{4}{*}{$\begin{array}{l}\text { Retrieved and modified from Riordan } \\
\text { (2016) }\end{array}$} \\
\hline & & Data analysis & 17 & \\
\hline & & Leadership & 25 & \\
\hline & & Communication & 32 & \\
\hline \multirow[t]{3}{*}{$\mathrm{E}$} & \multirow{3}{*}{$\begin{array}{l}\text { Climate change } \\
\text { mitigation and } \\
\text { adaptation } \\
\text { practices }\end{array}$} & Sustainable development & 11 & \multirow{3}{*}{$\begin{array}{l}\text { Retrieved and modified from Stacy } \\
\text { (2016), Hanifah \& Shaharudin (2016), } \\
\text { Hanifah et al. (2015) and Ministry of } \\
\text { Natural Resources and Environment } \\
\text { Malaysia (2010) }\end{array}$} \\
\hline & & $\begin{array}{l}\text { Environmental and natural } \\
\text { resources conservation }\end{array}$ & 24 & \\
\hline & & Effective engagement & 30 & \\
\hline
\end{tabular}




\section{Data Analysis Methods}

The data analysis methods in this study involved reliability tests and descriptive analysis of the level of study variables. Babbie (1992) stated that the reliability test is identified through the Cronbach's Alpha values classified by reliability index, in which $.90-1.00$ is very high, .70-.89 is high, .30-.69 is moderate and $.00-.30$ is low. Table 3 shows that the overall reliability values of each study variable exceed .70 of Cronbach's Alpha as suggested by most researchers, except for the psychomotor subvariable under the variables with Cronbach's Alpha value of .655. However, this item was accepted based on Salleh \& Zaidatun's (2001) opinions that an instrument with a coefficient value greater than .60 may be regarded as an instrument with a high-reliability value.

Descriptive analysis is used to clarify or summarise the information of a population or sample. Descriptive analysis can be used to explain data or information by summarising several sets of data or information into various mediums, such as tables or diagrams. To classify climate change knowledge, climate change mitigation and adaptation attitudes, climate change mitigation and adaptation skills and climate change mitigation and adaptation practices, a benchmark by Landell (2007) were used as shown in Table 4.

Table 3. Reliability of Study Questionnaire

\begin{tabular}{llcc}
\hline Variables & Sub Variables & $\begin{array}{c}\text { Number of } \\
\text { Items }\end{array}$ & Alpha Cronbach Values \\
\hline Climate literacy knowledge & Environment & 18 & .953 \\
& Social & 9 & .846 \\
& Economy & 10 & .922 \\
Climate change mitigation and & Cognitive & 8 & .919 \\
adaptation attitudes & Affective & 7 & .842 \\
& Psychomotor & 5 & .655 \\
Climate change mitigation and & Research and innovation & 7 & .918 \\
adaptation skills & Data analysis & 10 & .972 \\
& Leadership & 8 & .914 \\
& Communication & 7 & .953 \\
Climate change mitigation and & Sustainable development & 11 & .915 \\
adaptation practices & Environmental and natural & 5 & .951 \\
& resources conservation & 13 & .948 \\
\hline
\end{tabular}

Table 4. Mean Score Classification Level

\begin{tabular}{ll}
\hline Mean Score & Level \\
\hline $1.00-2.33$ & Low \\
$2.34-3.66$ & Medium \\
$3.67-5.00$ & High \\
\hline
\end{tabular}

Source: Landell (2007) 


\section{FINDINGS AND DISCUSSION Findings}

The findings and discussion of this study involved respondents' backgrounds and their level of climate change knowledge, climate change mitigation and adaptation attitudes, climate change mitigation and adaptation skills and climate change mitigation and adaptation practices. Table 5 shows the respondents' demographic backgrounds, which includes age, state of origin, semester, sex, race, respondents' father's education, mother's education, father's occupation, and mother's occupation. The majority of respondents were in the age range of 21 to 28 years old, and most were 24 years of age $(46.2 \%)$. Concerning the semester course of the respondents, $49(9.8 \%)$ were semester six students, $90(18.0 \%)$ were semester seven students and $361(72.2 \%)$ were in semester eight of the course. As for the respondents' sex, 120 $(24.0 \%)$ male respondents were involved in this study, and the rest were female which accounted for $380(76.0 \%)$ students. The racial fraction of the respondents consisted of four groups, namely the Malays with 357 (71.4\%) students, followed by Chinese with $48(9.6 \%)$ students, Indians with $34(6.8 \%)$ students, Sabah Bumiputera with $50(10.0 \%)$ students and Sarawak Bumiputera with $11(2.2 \%)$ students.

Table 5. Respondents' Demographic Background

\begin{tabular}{llcc}
\hline Background of Respondents & $\mathbf{N}$ & $\mathbf{\%}$ \\
\hline Semester & Semester 6 & 49 & 9.8 \\
& Semester 7 & 90 & 18.0 \\
& Semester 8 & 361 & 72.2 \\
& Total & $\mathbf{5 0 0}$ & $\mathbf{1 0 0}$ \\
\cline { 2 - 4 } Gender & Male & 120 & 24.0 \\
& Female & 380 & 76.0 \\
& Total & $\mathbf{5 0 0}$ & $\mathbf{1 0 0}$ \\
\cline { 2 - 4 } Races & Malay & 357 & 71.4 \\
& Chinese & 48 & 9.6 \\
& India & 34 & 6.8 \\
& Bumiputera Sabah & 50 & 10.0 \\
& Bumiputera Sarawak & 11 & 2.2 \\
& Total & $\mathbf{5 0 0}$ & $\mathbf{1 0 0}$ \\
\hline
\end{tabular}

The analysis of levels included the level of climate literacy knowledge, climate change mitigation and adaptation attitudes, climate change mitigation and adaptation skills and climate change mitigation and adaptation practices. The classification was based on the mean score classification level by Landell (2007) as in Table 4. Table 6 shows the overall variables of climate literacy knowledge, with 6 people $(1.2 \%)$ who were at low levels, 86 people $(17.2 \%)$ who were at moderate levels and 408 people (81.6\%) who were at high levels. The level of the climate literacy knowledge of the respondents was generally at high levels (mean $=4.12$ and $\mathrm{SP}=.57$ ). As for the environmental knowledge sub-variable, 8 people $(1.6 \%)$ were at low levels, 75 people $(15.0 \%)$ were at moderate levels and 417 people (83.4\%) were at high levels. The respondents' environmental knowledge sub-variable was generally at high levels (mean $=4.16$ and $\mathrm{SP}=$ $.65)$. The respondent's social knowledge subvariable clearly showed that 19 people $(3.8 \%)$ were at low levels, 16 people $(3.2 \%)$ were at moderate levels and 465 people $(93.0 \%)$ were at high levels. Clearly, the respondents' social knowledge sub-variable was at a high level (mean $=4.33$ and $\mathrm{SP}=.66$ ). As for the last one, the respondents' knowledge in economy subvariable, 24 people $(4.8 \%)$ were at low levels, 169 people $(33.8 \%)$ were at moderate levels and 307 people $(61.4 \%)$ were at high levels.

Table 7 shows the overall climate change mitigation and adaptation attitudes, in which 3 people $(.6 \%)$ were at low levels, 159 people $(31.8 \%)$ were at moderate levels and 338 people $(67.6 \%)$ were at high levels. This demonstrates that the respondents' climate change mitigation and adaptation attitudes were generally at a high level (mean $=3.86$ and SP $=.50)$. As for the cognitive attitude sub-variable, 16 people $(3.2 \%)$ were at low levels, 11 people $(2.2 \%)$ were at moderate levels, 473 people (94.6\%) were at high levels. Evidently, the respondents' cognitive attitude sub-variable was generally at a high level (mean $=4.31$ and $\mathrm{SP}=.65$ ). As for the respondents' affective attitude sub-variable, it clearly shows that the low levels were made up of 3 people $(.6 \%)$, while 40 people $(8.0 \%)$ were at moderate levels and 457 people $(91.4 \%)$ were at high levels.

Table 8 shows the overall climate change mitigation and adaptation skills; the low levels were made up of 78 people (15.6\%), 299 people $(59.8 \%)$ were at moderate levels and 123 people $(24.6 \%)$ were at high levels. This demonstrates 
Table 6. Level of Climate Literacy Knowledge

\begin{tabular}{lccccccccc}
\hline \multirow{2}{*}{ Variables } & \multicolumn{2}{c}{ Low Level } & \multicolumn{2}{c}{ Medium Level } & \multicolumn{2}{c}{ High Level } & Mean & SD & \multicolumn{2}{c}{$\begin{array}{c}\text { Level of } \\
\text { Mean }\end{array}$} \\
& $\mathbf{N}$ & $\mathbf{\%}$ & $\mathbf{N}$ & $\mathbf{\%}$ & $\mathbf{N}$ & $\mathbf{\%}$ & & High \\
\hline Climate Literacy & 6 & 1.2 & 86 & 17.2 & 408 & 81.6 & 4.12 & .57 & High \\
Knowledge & & & & & & & & & \\
Environment & 8 & 1.6 & 75 & 15.0 & 417 & 83.4 & 4.16 & .65 & High \\
Social & 19 & 3.8 & 16 & 3.2 & 465 & 93.0 & 4.33 & .66 & High \\
Economy & 24 & 4.8 & 169 & 33.8 & 307 & 61.4 & 3.87 & .83 &
\end{tabular}

Table 7. Level of Climate Change Mitigation and Adaptation Attitudes

\begin{tabular}{lccccccccc}
\hline \multirow{2}{*}{ Variables } & \multicolumn{2}{c}{ Low Level } & \multicolumn{2}{c}{ Medium Level } & \multicolumn{2}{c}{ High Level } & Mean & \multicolumn{2}{c}{$\begin{array}{c}\text { SD } \\
\text { Level of } \\
\text { Mean }\end{array}$} \\
\hline Climate Change & $\mathbf{N}$ & $\mathbf{\%}$ & $\mathbf{N}$ & $\mathbf{\%}$ & $\mathbf{N}$ & $\mathbf{\%}$ & & & High \\
$\begin{array}{l}\text { Mitigation and } \\
\text { Adaptation Attitudes }\end{array}$ & & .6 & 159 & 31.8 & 338 & 67.6 & 3.86 & .50 & \\
Cognitive & 16 & 3.2 & 11 & 2.2 & 473 & 94.6 & 4.31 & .65 & High \\
Affective & 3 & .6 & 40 & 8.0 & 457 & 91.4 & 4.36 & .60 & High \\
Psychomotor & 264 & 52.8 & 141 & 28.2 & 95 & 19.0 & 2.46 & 1.18 & Medium \\
\hline
\end{tabular}

that the respondents' climate change mitigation and adaptation skills were generally at moderate levels (mean $=3.14$ and $\mathrm{SP}=.78)$. As for the research and innovation sub-variable, 83 people $(16.6 \%)$ were at low levels, 241 people $(48.2 \%)$ were at moderate levels and 176 people $(35.2 \%)$ were at high levels. Clearly, the respondents' research and innovation sub-variable were generally at moderate levels (mean $=3.37$ and $\mathrm{SP}=.91)$. The respondents' data analysis subvariable significantly shows that the low levels were made up of 154 people (30.8\%), 221 people
$(44.2 \%)$ were at moderate levels and 125 people $(25.0 \%)$ were at high levels. The respondents' data analysis sub-variable was generally at a moderate level $($ mean $=2.92$ and $\mathrm{SP}=1.08$ ). Next, the respondents' leadership sub-variable clearly showed that 192 people $(38.4 \%)$ were at low levels, 187 people $(37.4 \%)$ were at moderate levels and 121 people $(24.2 \%)$ were at high levels. Obviously, the respondents' leadership sub-variable was generally at a moderate level $($ mean $=2.92$ and $\mathrm{SP}=.95)$.

Table 8. Level of Climate Change Mitigation and Adaptation Skills

\begin{tabular}{|c|c|c|c|c|c|c|c|c|c|}
\hline \multirow{2}{*}{ Variables } & \multicolumn{2}{|c|}{ Low Level } & \multicolumn{2}{|c|}{ Medium Level } & \multicolumn{2}{|c|}{ High Level } & \multirow{2}{*}{ Mean } & \multirow{2}{*}{ SD } & \multirow{2}{*}{$\begin{array}{c}\text { Level of } \\
\text { Mean }\end{array}$} \\
\hline & $\mathbf{N}$ & $\%$ & $\mathbf{N}$ & $\%$ & $\mathbf{N}$ & $\%$ & & & \\
\hline $\begin{array}{l}\text { Climate Change } \\
\text { Mitigation and } \\
\text { Adaptation Skills }\end{array}$ & 78 & 15.6 & 299 & 59.8 & 123 & 24.6 & 3.14 & .78 & Medium \\
\hline $\begin{array}{l}\text { Research and } \\
\text { Innovation }\end{array}$ & 83 & 16.6 & 241 & 48.2 & 176 & 35.2 & 3.37 & .91 & Medium \\
\hline Data Analysis & 154 & 30.8 & 221 & 44.2 & 125 & 25.0 & 2.92 & 1.08 & Medium \\
\hline Leadership & 192 & 38.4 & 187 & 37.4 & 121 & 24.2 & 2.92 & .95 & Medium \\
\hline Communication & 84 & 16.8 & 257 & 51.4 & 159 & 31.8 & 3.28 & .88 & Medium \\
\hline
\end{tabular}


Table 9. Level of Climate Change Mitigation and Adaptation Practices

\begin{tabular}{|c|c|c|c|c|c|c|c|c|c|}
\hline \multirow{2}{*}{ Variables } & \multicolumn{2}{|c|}{ Low Level } & \multicolumn{2}{|c|}{ Medium Level } & \multicolumn{2}{|c|}{ High Level } & \multirow{2}{*}{ Mean } & \multirow{2}{*}{ SD } & \multirow{2}{*}{$\begin{array}{c}\text { Level of } \\
\text { Mean }\end{array}$} \\
\hline & $\mathbf{N}$ & $\%$ & $\mathbf{N}$ & $\%$ & $\mathbf{N}$ & $\%$ & & & \\
\hline $\begin{array}{l}\text { Climate Change } \\
\text { Mitigation and } \\
\text { Adaptation Practices }\end{array}$ & 12 & 2.4 & 250 & 50.0 & 238 & 47.6 & 3.62 & .67 & Medium \\
\hline $\begin{array}{l}\text { Sustainable } \\
\text { Development }\end{array}$ & 49 & 9.8 & 221 & 44.2 & 230 & 46.0 & 3.59 & .90 & Medium \\
\hline $\begin{array}{l}\text { Environmental and } \\
\text { Natural Resources } \\
\text { Conservation }\end{array}$ & 18 & 3.6 & 69 & 13.8 & 413 & 82.6 & 4.27 & .79 & High \\
\hline Effective Engagement & 110 & 22.0 & 226 & 45.2 & 164 & 32.8 & 3.15 & .92 & Medium \\
\hline
\end{tabular}

Table 9 shows the overall climate change mitigation and adaptation practices, where 12 people $(2.4 \%)$ were at low levels, 250 people $(50.0 \%)$ were at moderate levels and 238 people $(47.6 \%)$ were at high levels. This demonstrates that the respondents' climate change mitigation and adaptation practices were generally at moderate levels ( mean $=3.62$ and $\mathrm{SP}=.67$ ). As for the sustainable development sub-variable, 49 people $(9.8 \%)$ were at low levels, 221 people $(44.2 \%)$ were at moderate levels and 230 people $(46.0 \%)$ were at high levels. Clearly, the respondents' sustainable development subvariable was generally at a moderate level (mean $=3.59$ and SP $=.90)$. The respondents' conservation of nature and natural resources sub-variable clearly shows that 18 people $(3.6 \%)$ were at low levels, 69 people $(13.8 \%)$ were at moderate levels and 413 people $(82.6 \%)$ were at high levels. The level of respondents' nature and natural resources conservation sub-variable was generally at a high level (mean $=4.27$ and $\mathrm{SP}=$ .79). Lastly, as for the effective engagement subvariable, 110 people $(22.0 \%)$ were at low levels, 226 people $(45.2 \%)$ were at moderate levels and 164 people $(32.8 \%)$ were at high levels. The effective engagement practice sub-variable was generally at a moderate level (mean $=3.15$ and $\mathrm{SP}=.92)$.

\section{Discussion}

Overall finding for climate literacy has showed a significant level for almost all the preservice teacher as in Table 6. Meaning that, the preservice teacher had a very high knowledge in climate seemingly with the education level and general knowledge needed to be a teachers. The respondents' economic knowledge subvariable was generally at a high level (mean $=$ 3.87 and $\mathrm{SP}=.83$ ). These findings are consistent with Biesbroek, Swart, Carter, Cowan, Henrichs, Mela, Morecroft, \& Rey (2010), correlate where higher scientific knowledge can lead to effective behavior towards the negative effects of climate change. Apart from that, high knowledge in environmental, social and economic issues can help an individual in raising awareness about climate literacy issues. Generally, with the higher knowledge of the preservice teachers, they may be possess a good quality teacher in near future too.

Apart from the knowledge, preservice teacher also possess either high or moderate level in attitudes such as in Table 7. The respondents' affective attitude sub-variable was generally at a high level (mean $=4.36$ and SP $=.60$ ). Next, as for the respondents' attitudes in the psychomotor aspect, 264 people $(52.8 \%)$ were at low levels, 141 people $(28.2 \%)$ were at moderate levels and 95 people $(19.0 \%)$ were at high levels. The respondents' attitude in the psychomotor aspect was generally at a moderate level (mean $=2.46$ and $\mathrm{SP}=1.18)$. According to Christensen \& Knezek (2015), a concerned attitude towards nature, such as climate change, includes beliefs, influences and behavioral intentions that collaborate to express an attentive attitude towards environmental activities or issues. This at the same time demonstrates that positive attitudes towards the environment can 
create environmentally responsible behaviors, especially on the issues related to climate change (Bradley, Waliczek, \& Zajicek, 2010).

As for the skills level, where all variables show only medium skills as in Table 8 . communication sub-variable, 84 people $(16.8 \%)$ were at low levels, 257 people $(51.4 \%)$ were at moderate levels and 159 people $(31.8 \%)$ were at high levels as in Table 8. It clearly shows that the communication skills sub-variable was generally at a moderate level ( mean $=3.28$ and $\mathrm{SP}=.88$ ). The findings are consistent with the findings of a study by Rohani (2013) which showed that the skills among teachers were moderate in terms of climate change issues. It is, therefore, the duty of teacher-training institutions to provide exposure to climate change mitigation and adaptation skills, as the future teachers play a role in influencing students' behavior at school (Baharom, Johdi, \& Noraini, 2009). Most of the respondents still did not practice in schools and that's why the skills variables is at the medium level.

In term of practices as in Table 9, most of the findings showed the preservice teacher did not fully practices the knowledge they acquired which is correlate with the level of skills where it still at the medium level. These findings of climate change mitigation and adaptation practices are consistent with the findings of Karisan \& Topcu (2016), which suggested that the practice regarding the earth's climate change of the future teachers had improved and was at a moderate level. Also, a study by Ochieng \& Koske (2013) also shows that practices in climate change mitigation and adaption are needed because climate change is a threat to all human beings. Most of the respondents are still not eligible teachers to practise in school, they may have the high attitudes and practices when they're practising in schools.

Overall, it was found that climate literacy awareness among the final year students at Sultan Idris Education University was progressing and still in the process of improvement. This indicates that the government's efforts in the National Policy on Climate Change can be implemented in guiding government agencies, industries, communities and stakeholders in dealing with the challenges of climate change in a comprehensive and integrated manner. This policy emphasizes the strengthening of the country's capacity to reduce the impact of climate change while promoting mitigation measures that can enhance sustainable development (Ministry of Natural Resources and Environment Malaysia, 2010). However, in this study, it was discovered that the skills and practices of climate change mitigation and adaptation are still at moderate levels. Therefore, in enhancing a more practical literacy awareness, exposure to students in the form of an awareness campaign should be used, as well as providing direct exposure through practices and skills in practical terms on mitigation and adaptation of climate change (Hanifah \& Shaharudin, 2016).

Table 10 shows the overall simplify matrices for all variable's. Most of the preservice teachers has showed the lack in skills and practices. This can be understood by the lack of exposure to practise their skill during the study in university. What most important is they possess the knowledge on climate change with hope the level of skill and practices will increase when the go to schools as a teacher.

Table 10. Matrix of Variable Level

\begin{tabular}{|c|c|c|c|c|}
\hline Variable & Knowledge & Attitudes & Skills & Practices \\
\hline Knowledge & & High | High & High | Moderate & High | Moderate \\
\hline Attitudes & High | High & & High | Moderate & High | Moderate \\
\hline Skills & Moderate | High & Moderate | High & & Moderate | Moderate \\
\hline Practices & Moderate $\mid$ High & Moderate | High & Moderate $\mid$ Moderate & \\
\hline
\end{tabular}




\section{CONCLUSION}

The results of this study have shown that climate change mitigation and adaptation knowledge and attitudes were athighlevels among the students of Sultan Idris Education University, and they can be proud of this. However, as for climate change mitigation and adaptation skills and practices, the findings showed that both were at moderate levels and can be improved over time. The efforts made by the universities, educators, and ministries in improving students' climate literacy are praiseworthy, as the levels of knowledge and attitudes of the students on this issue are satisfactory. However, in enhancing students' skills and practices of climate change mitigation and adaptation, as well as helping to strengthen students' knowledge and attitudes, activities related to climate change should be planned more widely. Among the activities that can be implemented are starting environmental clubs, supporting environmental learning and preservation activities and increasing the number of research activities concerning climate change at universities.

\section{ACKNOWLEDGMENTS}

This paper is based on the research project entitled "Model dan Indikator Literasi Iklim untuk Pelajar Universiti Awam di Malaysia menggunakan Structural Equation Modelling". The authors would like to extend their gratitude to the Research Management and Innovation Centre (RMIC), Sultan Idris Education University (UPSI) for the University Special Research Grant (GPU 2017-0175-106-01) that helped fund the research

\section{REFERENCES}

Ahmad, E. Z., \& Nour, C. (2015). The effect of greenhouse gases on the earth's temperature. International Journal of Environmental Monitoring and Analysis, 3(2), 74-79. doi:10.11648/j. ijema.20150302.16.

Babbie, E. (1992). The practice of social research. Belmont, CA: Wadsworth, Inc.

Baharom, M., Johdi, S. M. \& Noraini, H. C. (2009, 10-12 March). Kepimpinan pendidikan berkesan. [Effective educational leadership]. Paper presented at the Seminar Kepengetuaan Kebangsaan Ke-VI, Universiti Malaya, Kuala Lumpur.

Biesbroek, G. R., Swart, R. J., Carter, T. R., Cowan, C., Henrichs, T., Mela, H., Morecroft, M. D. \& Rey, D. (2010). Europe adapts to climate change: comparing national adaptation strategies. Global Environmental Change, 20(3), 440-450. doi:10.1016/j.gloenvcha.2010.03.005.

Bloom, B. S. (1956). Taxonomy of educational objectives: The classification of educational goals. New York, NY: Longman, Green and Co.

Bradley, J. C., Waliczek, T. M., \& Zajicek, J. M. (2010). Relationship between environmental knowledge and environmental attitude of high school students. The Journal of Environmental Education, 30(3), 17-21. doi:10.1080/00958969909601873.

Christensen, R. \& Knezek, G. (2015). The climate change attitude survey: Measuring middle school student beliefs and intentions to enact positive environmental change. International Journal of Environmental \& Science Education, 10(5), 773-788. doi:10.12973/ijese.2015.276a.

Dupigny-Giroux, L-A. (2010). Exploring the challenges of climate science literacy: Lessons from students, teachers and lifelong learners. Geography Compass, 4(9), 1203-1217. doi:10.1111/j.17498198.2010.00368.x.

Franzen, B., Bennett, B., \& Wilder, M. (2017). Climate change education survey instruments. Online Survey Software. https://uwsp.az1.qualtrics.com/jfe/form/ SV_bOtOdmnzs9eAWvb.

Gioconda, M. M., Denisse, A. M., \& Alfredo, M. L. (2016). Down-turner syndrome: A case with double monoclonal chromosomal abnormality. Case Reports in Pediatrics, 1, 13-21. doi:10.1155/2016/8760504. 
Global and Region Climate Change. (2014). Tools for assessing and teaching climate literacy. $\quad \mathrm{http}: / /$ cimss.ssec.wisc.edu/ climatechange/nav/tools.html.

Hammond, G. (2007). Time to give due weight to the carbon footprint issue. Nature, 445(7125), 256. doi:10.1038/445256b.

Hanifah, M. \& Shaharuddin, I. (2016). Education for sustainable development in Malaysia: A study of teacher and student awareness. Geografia Malaysian Journal of Society and Space, 12(6), 77-88. http://ejournal. ukm.my/gmjss/article/view/18022/5627.

Hanifah, M., Shaharudin, I., Mohmadisa, H., Nasir, N., \& Yazid, S. (2015). Transforming sustainability development education in Malaysian schools through greening activities. Review of International Geographical Education Online, 5(1), 78-94. http:// http://rigeo.org/.

Hasan, A. F. (2007). Mengenal falsafah pendidikan. [Knowing education philosophy]. Kuala Lumpur: Utusan Publications \&Distributors Sdn Bhd.

Holdaway, D. (1979). The foundations of literacy. Sydney: Ashton Scholastic.

Kahan, D. M., Peters, E., Wittlin, M., Slovic, P., Ouellette, L. L., Braman, D. \& Mandel, G. (2012). The polarizing impact of science literacy and numeracy on perceived climate change risks. Nature Climate Change, 2, 732-735. doi:10.1038/ nclimate1547.

Kamarudin, H. (2010). Psikologi pembelajaran. [Learning psychology]. Kuala Lumpur: Utusan Publications \&Distributors Sdn Bhd.

Karisan, D. \& Topcu, M. S. (2016). Contents exploring the preservice science teachers' written argumentation skills: The global climate change issue. International Journal of Environmental \& Science Education, 11(6), 1347-1363. doi:10.12973/ijese.2016.350a.
Krathwohl, D. R. (2002). A revision of Bloom's taxonomy: An overview. Theory into Practice, 41(4), 212-218. doi:10.1207/ s15430421tip4104 2.

Landell, K. (2007). Management by Menu (4 $4^{\text {th }}$ ed). London: Wiley \& Sons Inc.

Ledley, T. S., Gold, A. U., Niepold, F. \& McCaffrey, M. (2014). Moving toward collective impact in climate change literacy: The Climate Literacy and Energy Awareness Network (CLEAN). Journal of Geoscience Education, 62(3), 307-318. doi:10.5408/13-057.1.

Melillo, J., Richmond, T., \& Yohe, G. (Eds). (2014). Climate change impacts in the United States: The third national climate assessment. USA: U.S. Global Change Research Program. doi:10.7930/ J0Z31WJ2.

Ministry of Natural Resources and Environment Malaysia. (2010). Dasar Perubahan Iklim Negara. [National Climate Change Policy]. Putrajaya: Author. https:// www.mestecc.gov.my/web/wp-content/ uploads/2019/04/11.-Dasar-PerubahanIklim-Negara-dwi-bahasa.pdf.

Mohamad, T. B. \& Zurida, I. (2010). Literasi iklim: Pandangan dan kefahaman guru-guru pelatih tentang perubahan iklim. [Climate literacy: The view and understanding of preservice teachers on climate change]. Pendidikan Sains, 10(1), 50-62.

Niepold, F., Herring, D., \& McConville, D. (2007, 5-9 June). The case for climate literacy in the 21st century. Paper presented at the 5th International Symposium on Digital Earth, San Franciso Bay, CA, USA.

Ochieng, M. A. \& Koske, J. (2013). The level of climate change awareness and perception among primary school teachers in Kisumu Municipality, Kenya. International Journal of Humanities and Social Science, 3(21), 174-179. http://ir-library.ku.ac.ke/ handle/123456789/12223. 
OHCHR (The Office of the United Nations High Commissioner for Human Rights). (2015). Analytical study on the impacts of climate change on the enjoyment of the right to health. Questionnaire in English. http://www.ohchr.org/Documents/Issues/ ClimateChange/Impact/Questionnaire en.doc.

Riordan, L. (2016, 14 August). Five crucial skills we'll need to actually fight climate change. https://www.sciencealert.com/ five-crucial-skills-we-ll-need-to-actuallyfight-climate-change.

Rohani, J. S. (2013). Kesedaran teknologi hijau dalam kalangan warga Universiti Tun Hussein Onn Malaysia. [Green technology awareness among Malaysia Tun Hussein Onn University staff (Master's Thesis, Universiti Tun Hussein Onn Malaysia). http://eprints.uthm.edu. my/id/eprint/4210/.

Salleh, A. \& Zaidatun, T. (2001). Pengenalan analisis data berkomputer SPSS 10.0 for window. [Introduction to computer data analysis SPSS 10.0 for window]. Kuala Lumpur: Venton Publishing.

Schwartz, N. E. (1976). Nutrition knowledge, attitudes and practices of Canadian public health nurses. Journal of Nutrition Education, 8(1), 28-31. doi:10.1016/ S0022-3182(76)80113-6.

Stacy, A. A. H. (2016). Knowledge, attitudes \& practices study on climate change adaptation \& mitigation in Guyana. Guyana: UNDP.

Subramaniam, K. (2014). Perubahan iklim dan kesan kepada kesihatan persekitaran. [Climate change and impact to environmental health]. http://jkt.kpkt.gov. $\mathrm{my} / \mathrm{jkt} /$.
Suziana, Y. (2013). Pengetahuan dan Sikap pelajar terhadap masyarakat rendah karbon dalam kurikulum sains sekolah menengah. [Student knowledge and attitudes towards low carbon community in secondary school curriculum]. (Doctoral Dissertation, Universiti Teknologi Malaysia). http://eprints.utm. my/id/eprint/48260/.

Szczytkoa, R., Stevensona, K., Petersonb, M. N., Nietfeldc, J., \& Strnad, R. L. (2018). Development and validation of the environmental literacy instrument for adolescents. Environmental Education Research, 1-18. doi:10.1080/13504622.2 018.1487035 .

UK Environment Change Network. (2016). Observed impacts. http://www.ecn.ac.uk/ what-we-do/education/tutorials-weatherclimate/climate/climate-change-impacts/ observed-impacts.

UNDP (United Nations Development Programme). (2011). Human development report 2011, sustainability and equity: $A$ better future for all. New York, NY: United Nations Development Programme.

United Nations. (2009). Charting a new lowcarbon route to development United Nations Development Programme: A primer on integrated climate change planning for regional governments. New York, NY: United Nations.

Von Bertalanffy, L. (1968). General systems theory. One Park Avenue, NY: George Braziller, Inc.

WHO (World Health Organization). (2016). Climate change and human health-risks and responses. http://www.who.int/ globalchange/summary/en/index7.html. 